\title{
Mobility of copper and cobalt in metalliferous ecosystems: Results of a lysimeter study in the Lubumbashi Region (Democratic Republic of Congo)
}

\author{
Donato Kaya Muyumba ${ }^{\mathrm{a}, \mathrm{b}}$, Olivier Pourret ${ }^{\mathrm{c}}$, Amandine Liénard ${ }^{\mathrm{a}, *}$, Jessica Bonhoure ${ }^{\mathrm{c}}$, \\ Grégory Mahy ${ }^{\mathrm{a}}$, Michel Ngongo Luhembwe ${ }^{\mathrm{b}}$, Gilles Colinet ${ }^{\mathrm{a}}$ \\ ${ }^{a}$ University of Liège - Gembloux Agro-Bio Tech, Department of BIOSystem Engineering (BIOSE), Passage des Déportés, 2, B-5030 Gembloux, Belgium \\ ${ }^{\mathrm{b}}$ Faculty of Agricultural Sciences, Université de Lubumbashi, 1825 Kasapa street, University Campus, Lubumbashi, Democratic Republic of the Congo \\ ${ }^{\mathrm{c}}$ UniLaSalle, AGHYLE, 19 rue Pierre Waguet, 60026 Beauvais cedex, France
}

\section{A R T I C L E I N F O}

\section{Keywords:}

Trace elements

Copper

Cobalt

Mobility/bioavailability

Lysimeter

Rock weathering

Soil horizons

\begin{abstract}
A B S T R A C T
This paper presents the results of a lysimeter experiment in which a forest soil has been artificially spiked with rock fragments from natural copper $(\mathrm{Cu})$ and cobalt $(\mathrm{Co})$-hills from Tenke-Fungurume (Democratic Republic of Congo). The $\mathrm{Cu}$ and Co contents of the percolating water have been analysed at repeated intervals and the impact of rock on the soil properties was evaluated at the end of the experiment. Five rocks were sampled in one copper hill. In natural conditions, these rock fragments located on the top of the hill are mixed to surface soil horizon along the slope through colluvial processes. The $\mathrm{Cu}$ and Co contents in rocks range respectively between $470 \mathrm{mg} / \mathrm{kg}$ (siliceous rock) and 140,000 mg/kg (shale) and between $450 \mathrm{mg} / \mathrm{kg}$ (dolostone) and $5300 \mathrm{mg} / \mathrm{kg}$ (shale). Rock fragments were mixed with two horizons (hemi-organic A with $2.7 \%$ total organic carbon (TOC), and mineral B with $0.3 \%$ TOC) of an acid ( $\mathrm{pH}$ water $<4.5$ ) acrisol under forest. The mixture was placed in $1 \mathrm{~L}$ lysimeters and left in Lubumbashi ex situ conditions during the rainy season. Percolating water was collected for six periods after and the $\mathrm{Cu}$ and Co contents have been analysed. At the end of the experiment, soil from the lysimeter was removed for $\mathrm{pH}$, TOC, available nutrients and trace elements, $\mathrm{CaCl}_{2}$-extractable $\mathrm{Cu}$ and $\mathrm{Co}$ analysis.

The results show great differences between $\mathrm{Cu}$ and Co releases in the percolating solutions according to the nature of the rocks. The quantities released were correlated to the concentrations originally present in the unweathered rocks. Differences were also found between the A and B horizons, which indicate that the physicochemical properties of the soil influence reaction with the rocks. The differences between both horizons are mainly organic carbon content, cationic exchange capacity and nutrient content, which were higher in the A horizon. However, the $\mathrm{pH}$ of the A horizon was acidic compared with the B horizon.

Significant correlations were found between extractable $\mathrm{Cu}$ and $\mathrm{Co}$ with concentrations of their leaching solution. Because of this, soluble $\mathrm{Cu}$ and $\mathrm{Co}$ extracted by $\mathrm{CaCl}_{2}$ can be regarded as vertical transfer risk prediction tools of $\mathrm{Cu}$ and $\mathrm{Co}$ in the soil.
\end{abstract}

\section{Introduction}

Mineral resources have been exploited in the Democratic Republic of Congo (DRC) for thousands of years. Abandoned metalliferous mine wastes, containing high concentrations of metals, were deposited on the surface, which resulted in the pollution of the surrounding terrestrial and aquatic ecosystems (Banza et al., 2009; Narendrula et al., 2012; Pourret et al., 2016). The presence of copper (Cu) and cobalt (Co) deposits and related mining are at the base of contamination of soil and living organisms. To develop phytostabilization further, as well as restoration of biodiversity, research has been conducted in natural ecosystems of some copper hills to evaluate $\mathrm{Cu}$ and Co mobility in soil-plant systems (Faucon et al., 2012; Lange et al., 2014; Pourret et al., 2016; Séleck et al., 2013).

Metalliferous soils from geological anomalies result from the weathering of rocks that are naturally rich in $\mathrm{Cu}$ and $\mathrm{Co}$. The distribution of $\mathrm{Cu}$ and $\mathrm{Co}$ in the landscape is driven by various processes, including erosion and vertical transfers in soils (Muyumba et al., 2015). The transformation of a rock in soil depends on two main stages, namely, the alteration (physical and chemical alteration) of the parent material and soil formation (Kabata-Pendias, 2010). The stability of the mineral and the physico-chemical properties of trace elements (TEs)

\footnotetext{
* Corresponding author.

E-mail addresses: amandine.lienard@uliege.be (A. Liénard), Gilles.Colinet@uliege.be (G. Colinet).
} 


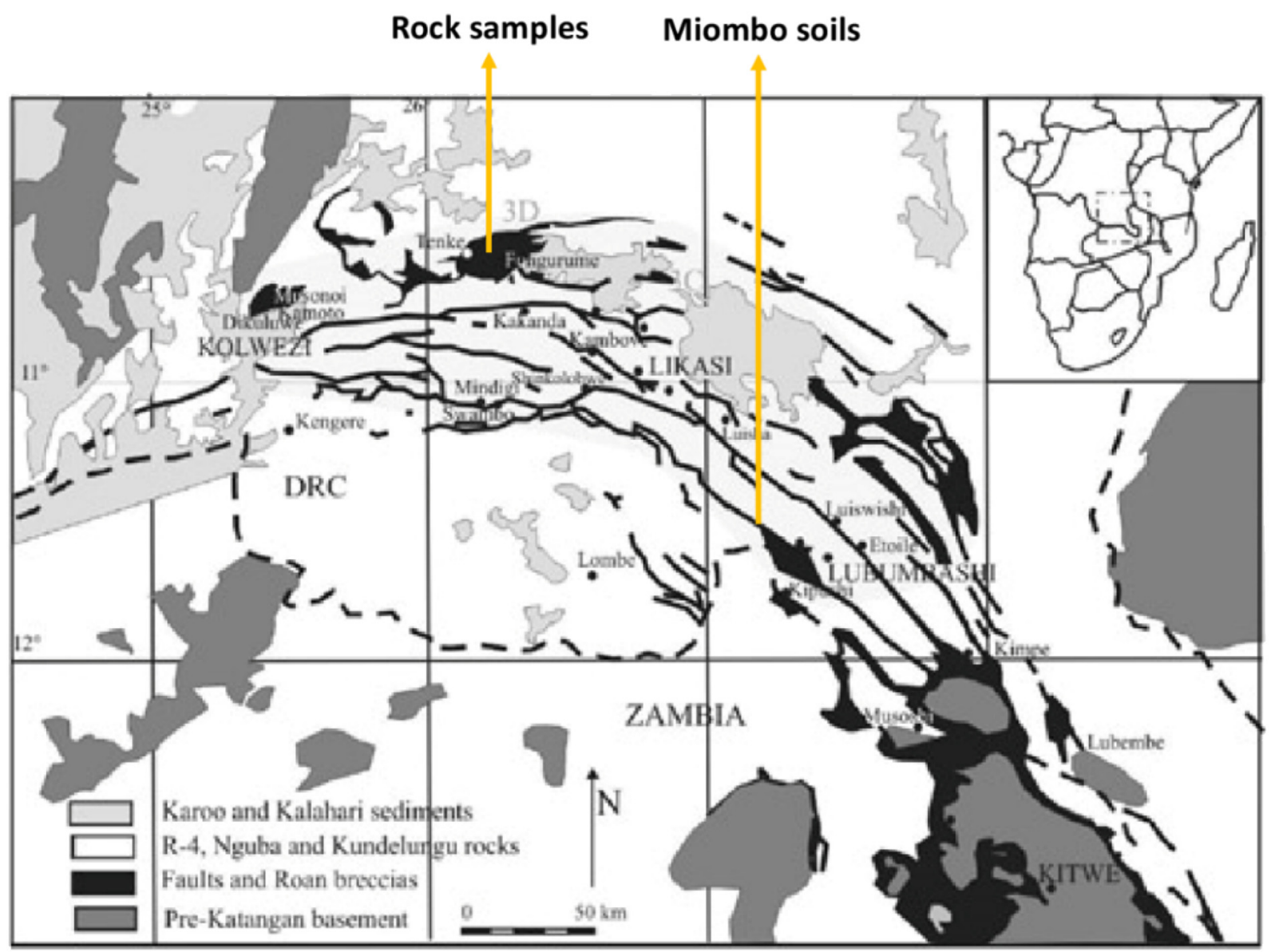

Fig. 1. Sampling location of Miombo soils (S) and rocks (R) in Katanga Copperbelt.

(Modified from Cailteux et al. (2005).)

determine their mobility during the weathering process (KabataPendias, 2010). The basic process of alteration can be summarized in dissolution, hydration, hydrolysis, oxidation, reduction and carbonation (Kabata-Pendias, 2010). According to the soil conditions (i.e., pH, organic matter content, metal concentrations, redox condition), $\mathrm{Cu}$ and Co released from the parent materials are distributed in different soil phases, namely, solid, colloidal and soluble soil phases. These phases and their interactions determine the fate and transport of TEs in the environment (Hooda, 2010). Moreover, mobility of TE in the environment may be quantified using a sorption isotherm (Limousin et al., 2007). The mobility of Cu and Co also depends on the physicochemical properties of different phases of soil (Hooda, 2010). Some of the soil parameters, such as $\mathrm{pH}$, total organic carbon, total metal concentration, iron and manganese oxides and hydroxides influence the distribution of TE in soil (e.g. for Co: Collins and Kinsela, 2010). These properties and soil constituents can control the mobility and speciation of chemical elements in the soil system. Carbonates, phosphates, iron/manganese oxides and organic material are some of the soil constituents that act in the retention and release of elements in soils.

Copper and Co ore deposits are scattered in the south of Katanga province in DRC (Muyumba et al., 2015). Metalliferous rock fragments are usually located on the tops of hills and their weathering produces various materials rich in $\mathrm{Cu}$ and $\mathrm{Co}$ that contaminate the surface soil downstream the slope. Metal transfer in these systems occurs either in particulate, colloidal or soluble forms. The distribution of vegetation is affected by the concentration of bioavailable $\mathrm{Cu}$ and $\mathrm{Co}$ forms and chemical factors that influence them (Faucon et al., 2011; Ilunga wa Ilunga et al., 2013; Saad et al., 2012; Séleck et al., 2013). The diversity of $\mathrm{Cu}$ and $\mathrm{Co}$ chemical fractions in soil influences plant species diversity by increasing or decreasing $\mathrm{Cu}$ and Co bioavailability (Faucon et al., 2016). The contribution of rock material to surface contamination (natural or anthropogenic) in ecosystems results from contact between a non-contaminated substratum and $\mathrm{Cu}-\mathrm{Co}$-rich minerals and subsequent evolution under the physicochemical conditions of the affected substrate. According to their mobility and bioavailability, $\mathrm{Cu}$ and $\mathrm{Co}$ can be transferred into soil, water, plants and therefore the food chain (Banza et al., 2009; Katemo Manda et al., 2010; Lange et al., 2014; Mwanamoki et al., 2014; Lange et al., 2017).

Non metalliferous soils in this part of Katanga are characterized by woodland called Miombo (Duvigneaud, 1958; Pourret et al., 2016). They are exposed to natural contamination sources (from anomalies) and anthropogenic contamination sources that are related to mining activities. In this case, contamination may affect the surface layers rich in organic matter (OM) or deeper layers poor in OM. The weathering of Cu- and Co-rich minerals, in contact with the soil of these two layers, might release their chemical elements, which will be redistributed in the various phases of the soil. This scenario is typical for the transfer of elements from their parent materials to the soil due to the storage of tailings waste (e.g. waste from mining; Lottermoser, 2010) but also by what is actually occurring downslope of the outcrops of $\mathrm{Cu}$ and Co rich rocks in the copper hills ecosystems.

The aim of this study is to go further in the understanding of the reaction between metal-rich materials and soils and of the processes affecting the mobility of $\mathrm{Cu}$ and $\mathrm{Co}$ in the natural ecosystems. Specific objectives are (i) to assess the potential contribution of $\mathrm{Cu}$ and Co rich rocks to the contamination of soil and (ii) to evaluate the mobility of $\mathrm{Cu}$ and Co released into the soil solution according to the properties of soils. One outdoor lysimeter study has been conducted to measure the 
dynamics of dissolution of rocks from the metalliferous ecosystems of Fungurume in a typical soil that can be found in the surrounding Miombo woodland and evaluate the potential contribution of these rocks to the mobile pools of $\mathrm{Cu}$ and $\mathrm{Co}$ in soils. Two additional studies were conducted under laboratory conditions to characterize the effect of soil properties, mainly $\mathrm{pH}$ and total organic content, on metal solubility and sorption on solid phases.

\section{Materials and methods}

\subsection{Study area}

The Katanga Copperbelt (Democratic Republic of Congo, Fig. 1) was selected for the present study as it acts as a major producer of $\mathrm{Cu}$ and $\mathrm{Co}$ accounting for $2.7 \%$ and $48.6 \%$ of the world production in 2016 , respectively (USGS, 2017). Katanga is known for $\mathrm{Cu}$ and Co ore deposits. Several world class deposits are exploited for these elements as the Tenke-Fungurume deposits (Fay and Barton, 2012; Mambwe et al., 2017). Over a century, mining has disseminated large quantities of waste in the environment and created secondary metalliferous substrates with elevated concentrations of $\mathrm{Cu}$ and Co (Pourret et al., 2016; Faucon et al., 2016). These natural hills are surrounded by Miombo woodlands (Ilunga wa Ilunga et al., 2013; Séleck et al., 2013), that will be considered as non-metalliferous natural sites (Pourret et al., 2016).

Mineralized rocks mainly appear as rounded hills, typically a few tenths of meters above the level of the surrounding non mineralized area; these hills are relics of a gossan (i.e., a weathered part of the copper and cobalt ores; Decrée et al., 2010; De Putter et al., 2010). Copper and Co hills present a gradient of $\mathrm{Cu}$ and $\mathrm{Co}$ concentrations in soils (about $0.1 \% \mathrm{Cu}$ total content at the bottom of hill and $5 \%$ at the top and about $0.05 \%$ Co total content at the bottom of hill and $1 \%$ at the top) and are mainly covered by steppic savanna which is characteristic vegetation of Katangan copper outcrops (i.e., old vegetation composed of perennial species with a highly developed underground system) (Séleck et al., 2013) (Fig. 2). The mineralization is essentially made up of a copper-cobalt ore, which occurs mainly as sulfides (chalcopyrite $\left(\mathrm{CuFeS}_{2}\right)$, chalcocite $\left(\mathrm{Cu}_{2} \mathrm{~S}\right)$, and covellite $(\mathrm{CuS})$ for $\mathrm{Cu}$, and carrollite $\left[\mathrm{Cu}\left(\mathrm{Co}, \mathrm{Ni}_{2} \mathrm{~S}_{4}\right]\right.$ for $\mathrm{Co}$ ), oxides (cuprite, $\mathrm{Cu}_{2} \mathrm{O}$; heterogenite, $\mathrm{CoOOH}$ ), carbonates (malachite, $\left.\mathrm{Cu}_{2}\left(\mathrm{CO}_{3}\right)(\mathrm{OH})_{2}\right)$, silicates [chrysocolla; $\left(\mathrm{Cu}, \mathrm{Al}_{2}\right)_{2} \mathrm{H}_{2} \mathrm{Si}_{2}-\mathrm{O}_{5}(\mathrm{OH})_{4} \cdot \mathrm{nH}_{2} \mathrm{O}$ ] and phosphates [pseudomalachite, $\left.\mathrm{Cu}_{5}\left(\mathrm{PO}_{4}\right)_{2}(\mathrm{OH})_{4}\right]$.

\subsection{Experimental set-up}

An open-air lysimeter study was conducted in Lubumbashi in Katanga province of DRC during the rainy season between November 2011 and March 2012. Leaching solutions and lysimeter soil were collected and sent to the Geopedology Laboratory (University of LiègeGembloux Agro-Bio Tech, Belgium) for analysis. Additional incubation and sorption experiments were conducted in the Geopedology Laboratory to characterize the fate of $\mathrm{Cu}$ and $\mathrm{Co}$ in soils contaminated by $\mathrm{Cu}$ and $\mathrm{Co}$ rich rocks.

For lysimeter and sorption experiments, a typical red soil under Miombo woodland in Katanga (Fig. 1) was sampled at two depths, $0-25 \mathrm{~cm}$ and $26-50 \mathrm{~cm}$ for the A and B horizons, respectively. The soil for the incubation experiment was the same type as the first one but under a cultivated area. Only the A horizon $(0-25 \mathrm{~cm})$ was sampled. Miombo soils are usually known as ferralsols under the WRB classification (Ngongo Luhembwe, 2014).

Five rock samples were taken in the outcrops of Fungurume according to their occurrence under steppic savannas and sward (Figs. 1 and 2). Samples are named according to the most recent stratigraphy of the Mine Series of the Roan group from the Katanga Supergroup (Fay and Barton, 2012; Kampunzu et al., 2009; Schuh et al., 2012). From oldest to most recent, they are DStrat (stratified, silicified dolomite), RSF (silicified laminated algal dolomite), RSC and RSCmin (silicified cavernous stromatolitic dolomite) and SDB (basal dolomitic siltstone/ shale). Each rock is known to be rich in $\mathrm{Cu}$ and $\mathrm{Co}$.

The rock samples were crushed and sieved to improve the contact area of mineralized rocks with soil and to standardize the size of grains between the different types of rocks. The final size of grains lies between 0.5 and $1 \mathrm{~mm}$. Fifty grams of crushed rock were mixed with $800 \mathrm{~g}$ of soil and poured into $1 \mathrm{~L}$ lysimeters. Three repetitions were done and the 36 lysimeters were installed in open-top boxes filled with quartz gravel in the experimental field of the University of Lubumbashi. Flexible medical pipes and $500 \mathrm{~mL}$ plastic bottles were used to collect the solution from the bottom of the lysimeters. The experimental device was covered by a polyethylene grid attached to a removable wooden frame to absorb the energy of raindrops and prevent splash sealing. After initial humidification of the soil-rock mixture at field capacity, drainage solutions were taken after 56, 88, 104, 117, 131 and 145 days and kept cold in a fridge prior to analysis in the Geopedology Laboratory. The experiment covered the rainy season between the beginning of November 2011 and end of March 2012. Leachate solution was filtered through a Whatman 602 paper filter (pore size $<2 \mu \mathrm{m}$ ) and acidified with $100 \mu \mathrm{L}$ of concentrated nitric acid. The

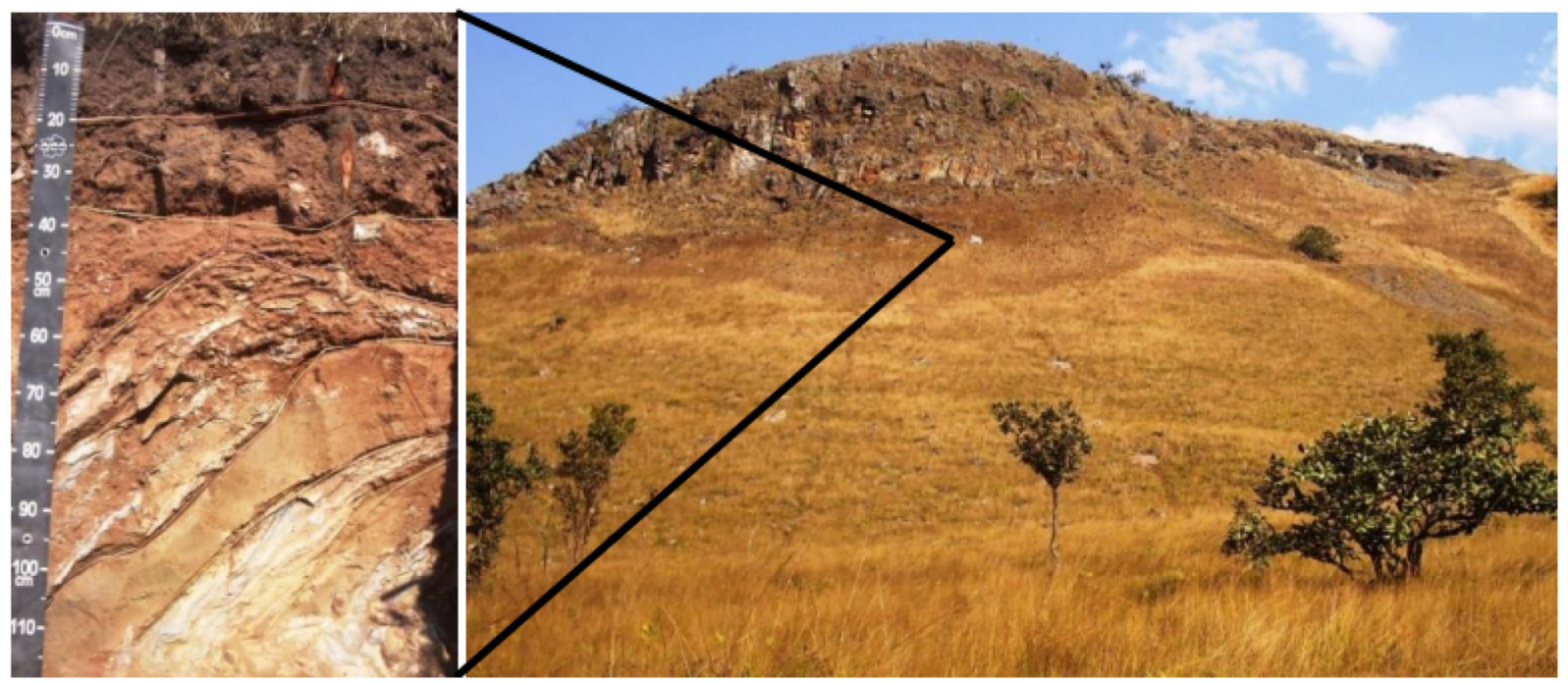

Fig. 2. A soil profile developed on the SDB rock in a Fungurume copper hill. 
Table 1

Properties of soils used for the lysimeter experiment.

\begin{tabular}{|c|c|c|c|c|c|c|c|c|c|c|c|c|c|c|c|c|c|c|c|c|}
\hline Soil & $\mathrm{pH}_{\mathrm{H} 2 \mathrm{O}}$ & $\mathrm{pH}_{\mathrm{KCl}}$ & TOC $^{\mathrm{a}}$ & Clay $^{b}$ & Silt $^{\mathrm{b}}$ & Sand $^{\mathrm{b}}$ & $\mathrm{CEC}^{\mathrm{c}}$ & $\mathrm{Al}_{\mathrm{HF}}{ }^{\mathrm{d}}$ & $\mathrm{Fe}_{\mathrm{HF}}^{\mathrm{d}}$ & $\mathrm{Mn}_{\mathrm{HF}}{ }^{\mathrm{d}}$ & $\mathrm{K}_{\mathrm{AA}}{ }^{\mathrm{e}}$ & $M g_{A A}{ }^{e}$ & $\mathrm{Ca}_{\mathrm{AA}}{ }^{\mathrm{e}}$ & $\mathrm{Cu}_{\mathrm{HF}}^{\mathrm{d}}$ & $\mathrm{Co}_{\mathrm{HF}}{ }^{\mathrm{d}}$ & $\mathrm{Cu}_{\mathrm{AA}}{ }^{\mathrm{d}}$ & $\mathrm{Co}_{\mathrm{AA}}{ }^{\mathrm{d}}$ & $\mathrm{Mn}_{\mathrm{AA}}{ }^{\mathrm{d}}$ & $\mathrm{Cu}_{\mathrm{CaCl} 2}{ }^{\mathrm{d}}$ & $\mathrm{Co}_{\mathrm{CaCl} 2}{ }^{\mathrm{d}}$ \\
\hline A & 4.4 & 3.9 & 2.7 & 31 & 34 & 36 & 25.4 & 2131 & 8971 & 261 & 14.7 & 9.9 & 1.4 & 158 & 44 & 20 & 2.4 & 53.2 & 0.3 & 1.0 \\
\hline B & 4.3 & 4.0 & 0.3 & 34 & 25 & 40 & 17.6 & 3056 & 12714 & 234 & 4.5 & 0.5 & 0.1 & 90 & 48 & 2 & 0.7 & 9.4 & 0.2 & 0.1 \\
\hline
\end{tabular}

HF: triacid HF digestion (NF ISO11466), AA: $\mathrm{CH}_{3} \mathrm{COONH}_{4}-\mathrm{EDTA}$ at pH 4.65 (Faucon et al., 2009) and $\mathrm{CaCl}_{2}$ : 0.01 mol/L CaCl 2 .

a $\mathrm{g} / 100 \mathrm{~g}$.

b $\%$.

c $\mathrm{cmol} / \mathrm{kg}$.

d $\mathrm{mg} / \mathrm{kg}$.

e $\mathrm{mg} / 100 \mathrm{~g}$.

concentrations of $\mathrm{Cu}$ and $\mathrm{Co}$ were measured by flame atomic absorption spectrometry (VARIAN 220, Agilent Technologies, Santa Clara, CA, USA). The detection limits for $\mathrm{Cu}$ and $\mathrm{Co}$ are $0.01 \mathrm{mg} / \mathrm{L}$. After six months, soils were carefully collected from the lysimeters, dried at room temperature, sieved at $2 \mathrm{~mm}$ and placed in plastic bags for analysis.

A sorption experiment was conducted on the same soils as used in the lysimeters. Three grams of soil from the A or B horizons were equilibrated for $16 \mathrm{~h}$ with $30 \mathrm{~mL}$ of a solution of $0.01 \mathrm{~mol} / \mathrm{L} \mathrm{Ca}\left(\mathrm{NO}_{3}\right)_{2}$ containing $0,0.03,0.06,0.15,0.30,0.60,1.50,3.00$ or $6.00 \mathrm{~g} / \mathrm{L}$ of $\mathrm{Cu}$ or $\mathrm{Co}$, with $\mathrm{NO}_{3}{ }^{-}$as a counterion. Solutions were then centrifuged at $3000 \mathrm{rpm}$ and filtered on Whatman 602 paper. The $\mathrm{pH}$ was measured in the extraction solution with a glass electrode. No significant change of $\mathrm{pH}$ was observed during experiment. The maximum added quantities of $\mathrm{Cu}$ and $\mathrm{Co}$, expressed in $\mathrm{cmol} / \mathrm{kg}$, are five to nine times lower than the cationic exchange capacity (CEC).

An additional incubation experiment was conducted to test the influence of $\mathrm{pH}$ and organic content changes on soil-soluble $\mathrm{Cu}$. Twenty grams of the A horizon of a slightly acid ferralsol (WRB) was contaminated with $200 \mathrm{mg}$ of $\mathrm{CuCO}_{3}$ or $100 \mathrm{mg}$ of $\mathrm{CuSO}_{4}$ (analytical grade) and received either liming $\left(\mathrm{CaCO}_{3}\right.$, D1 $(10 \mathrm{mg} / 20 \mathrm{~g})$, D2 $\left.(50 \mathrm{mg} / 20 \mathrm{~g})\right)$ or organic amendment (leaf and tree pruning compost, M1 (200 mg/ $20 \mathrm{~g}), \mathrm{M} 2(1000 \mathrm{mg} / 20 \mathrm{~g}))$. The pots were left incubating at $20^{\circ} \mathrm{C}$ and $80 \%$ of water field capacity for six months. Then, the $\mathrm{pH}$ and $\mathrm{Cu}$ concentration (atomic absorption spectrometry (AAS)) were measured in the $\mathrm{CaCl}_{2}$ extracts.

\subsection{Analytical procedure}

Soil samples were characterized before and after the experiment. The $\mathrm{pH}$ was measured with a glass electrode in either $\mathrm{H}_{2} \mathrm{O}, 1 \mathrm{~mol} / \mathrm{L} \mathrm{KCl}$ or $0.01 \mathrm{~mol} / \mathrm{L} \mathrm{CaCl}_{2}$ soil solution after $2 \mathrm{~h}$ of end-over-end agitation of $20 \mathrm{~g}$ of soil in $50 \mathrm{~mL}$ of solvent. Total organic carbon (TOC) was determined after $\mathrm{Cr}_{2} \mathrm{O}_{7}{ }^{2-}$ oxidation (Sparks, 2013). Particle size distribution was measured by the Robinson pipette (clay and silts) and sand weighing, after elimination of organic (with $\mathrm{H}_{2} \mathrm{O}_{2}$ ) and carbonate ion (with $\mathrm{HCl}$ ). No specific treatment for iron oxides was applied. The $\mathrm{CEC}$ was measured after saturation of the complex with $\mathrm{CH}_{3} \mathrm{COONH}_{4}$ at $\mathrm{pH}$ 7. The total, available and soluble elements were measured by flame atomic absorption (Varian 220) following triacid HF digestion (NF ISO11466), $\mathrm{CH}_{3} \mathrm{COONH}_{4}$-EDTA at pH 4.65 (Faucon et al., 2009) and $0.01 \mathrm{~mol} / \mathrm{L} \mathrm{CaCl}{ }_{2}$, respectively (Feng et al., 2005). The total contents of $\mathrm{Al}, \mathrm{Fe}, \mathrm{Mn}, \mathrm{Cu}$ and $\mathrm{Co}$ were measured for rock and initial soil samples after fine grinding at $200 \mu \mathrm{m}$. The available $\mathrm{Ca}, \mathrm{Mg}, \mathrm{K}, \mathrm{P}, \mathrm{Cu}$ and $\mathrm{Co}$ were measured in the soil before and after the experiment. The soluble $\mathrm{Cu}$ and $\mathrm{Co}$ were measured for every soil and rock sample. The $\mathrm{pH}$ was also measured in the $0.01 \mathrm{~mol} / \mathrm{L} \mathrm{CaCl}_{2}$ extracts before ion measurement. The concentrations of $\mathrm{Cu}$ and $\mathrm{Co}$ were measured by flame AAS (Varian 220). Protocol details can be found in Liénard et al. (2014).

The mineralogy of rock samples was determined by X-ray diffraction analysis (XRD; Philips diffractometer with a monochromatic detector and $\mathrm{CuK} \alpha$ radiation). Samples were scanned from 2 to $50^{\circ} 2 \theta$ and the EVA 2, version 13 equipped with the JCPDS PDF-2 database (ICDD,
2003) was used for qualitative analysis of the powder diagrams. The mineralogical composition of samples was further determined by optical microscopy, scanning electron microscopy (SEM) and energy dispersion spectrometry (EDS). Samples were examined under a Leica DRM-XP polarizing microscope in transmitted and reflected light and subsequently studied under a Hitachi S3400 SEM equipped with a ThermoNORAN NSS Ultradry EDS (Pourret et al., 2016) and further refined using previous studies from literature (Fay and Barton, 2012; Schuh et al., 2012; Decrée et al., 2015; Mambwe et al., 2017).

\section{Results}

\subsection{Soil characteristics}

The characteristics of the soil before the experiment are presented in Table 1. The properties of the A and B horizons of the soil were typical of red soils found around Lubumbashi (Mpundu Mubemba et al., 2014; Shutcha et al., 2010). The texture of both horizons was clay loam and soil reaction was very acidic $\left(\mathrm{pH}_{\mathrm{H} 2 \mathrm{O}}<4.5\right)$. They differed mainly by the organic carbon content $(2.7>0.3 \mathrm{~g} / 100 \mathrm{~g})$, the CEC and the nutrient status $\left(\mathrm{CH}_{3} \mathrm{COONH}_{4}\right.$-EDTA and $\mathrm{CaCl}_{2}$ extractable elements), which were higher in the surface horizon than in the subsurface (Table 1). The total Fe and $\mathrm{Al}$ contents, however, were higher in the $\mathrm{B}$ horizon. Indeed, soils of Katanga are often reported as equivalent to ferralsols. These soils are usually acidic $(\mathrm{pH}<5)$ but the levels of CEC found were largely higher than what is allowed in the definition of ferralsol ( $16 \mathrm{cmol} / \mathrm{kg}$; IUSS Working Group WRB, 2015). Eventually, the studied soil should, therefore, be considered as a typical alisol (Pourret et al., 2016).

\subsection{Rock characteristics}

The characteristics of the rocks used in the experiment are presented in Table 2. The results show that the selected rocks differ by their mineralogical content (Muyumba et al., 2015). The DStrat rock is a finegrained stratified dolomite; it contains dolomite and traces of malachite and heterogenite. After Kampunzu et al. (2005) and Schuh et al. (2012), geochemical data indicate that DStrat, RSF and RSC are extremely poor in alkalis and very rich in $\mathrm{MgO}$. RSC and RSCmin rocks are reef-type stromatolitic dolomites; they contain hematite, cuprite, and heterogenite. RSC is rather less rich in $\mathrm{Cu}$ and Co than RSCmin. The RSF rock is a silicified-stromatolitic dolomite and contains dolomite, hematite, malachite, and heterogenite. RSC and RSF are named as siliceous rocks (Cailteux et al., 2005); according to Schuh et al. (2012), RSC rock contains $>60 \%$ quartz. RSCmin has the same main mineralogy than RSC but this one is less rich on Cu than RSCmin. The SDB is a dolomitic shale and presents the highest content in $\mathrm{Cu}$, Co and $\mathrm{Al}$ and the lowest $\mathrm{pH}$ (5.9), which is consistent with the presence of sulfide ore minerals (pyrite, bornite, carrollite). The presence of muscovite illite in RSF and SDB is the source for high Al, $\mathrm{K}$ and Si (Schuh et al., 2012). The element contents found in this study were consistent with previous studies reported by Muyumba et al. (2015). 
Table 2

Rock properties and main associated mineralogy.

\begin{tabular}{|c|c|c|c|c|c|c|c|c|c|}
\hline Rock & $\mathrm{pH}_{\mathrm{CaCl} 2}$ & $\mathrm{Cu}_{\mathrm{CaCl} 2}^{\mathrm{a}}$ & $\mathrm{Co}_{\mathrm{CaCl} 2}^{\mathrm{a}}$ & $\mathrm{Cu}_{\mathrm{HF}}^{\mathrm{a}}$ & $\mathrm{Co}_{\mathrm{HF}}^{\mathrm{a}}$ & $\mathrm{Al}_{\mathrm{HF}}^{\mathrm{a}}$ & $\mathrm{Fe}_{\mathrm{HF}}^{\mathrm{a}}$ & $\mathrm{Mn}_{\mathrm{HF}}{ }^{\mathrm{a}}$ & Main mineralogy \\
\hline SDB & 5.9 & 72 & 27 & 141,811 & 5290 & 2583 & 484 & 19 & Qtz, Ilt/Mnt, Py, Man, Bn, Car \\
\hline RSC & 6.3 & $<1$ & 1 & 473 & 954 & 249 & 473 & 378 & Qtz, Ilt, Hem, Cpr, Het, \\
\hline RSCmin & 6.5 & 2 & 5 & 22,569 & 1700 & 332 & 253 & 57 & Qtz, Ilt, Hem, Cpr, Het, \\
\hline RSF & 6.7 & 6 & 14 & 95,353 & 3857 & 955 & 819 & 244 & Qtz, Dol, Ilt/Kln, Hem, Mlc, Het \\
\hline DStrat & 7.9 & $<1$ & $<\mathrm{dl}$ & 14,329 & 455 & 2525 & 3400 & 166 & Qtz, Dol, Ilt/Mnt, Tlc/Anh, Mlc, Het \\
\hline
\end{tabular}

HF: triacid HF digestion (NF ISO11466), AA: $\mathrm{CH}_{3} \mathrm{COONH}_{4}-\mathrm{EDTA}$ at pH 4.65 (Faucon et al., 2009) and CaCl $2: 0.01 \mathrm{~mol} / \mathrm{L} \mathrm{CaCl}_{2}$.

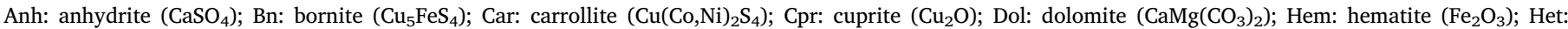

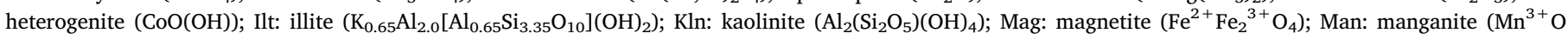

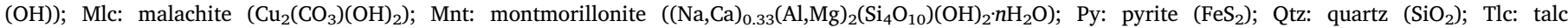
$\left(\mathrm{Mg}_{3} \mathrm{Si}_{4} \mathrm{O}_{10}(\mathrm{OH})_{2}\right)$.

${ }^{\mathrm{a}} \mathrm{mg} / \mathrm{kg}$.

Table 3

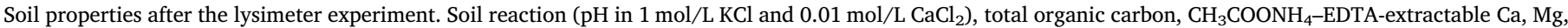

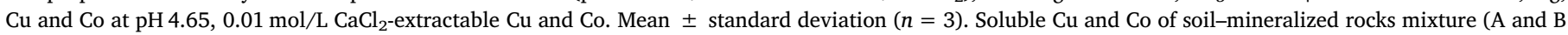
horizons, RSC, RSCmin, RSF, DStrat and SDB).

\begin{tabular}{|c|c|c|c|c|c|c|c|c|c|c|c|}
\hline Soil & Appl. $\mathrm{Cu}^{\mathrm{a}}$ & Appl. $\mathrm{Co}^{\mathrm{a}}$ & $\mathrm{pH}_{\mathrm{KCl}}$ & $\mathrm{pH}_{\mathrm{CaCl} 2}$ & TOC $^{\mathrm{b}}$ & $\mathrm{Ca}_{\mathrm{AA}}{ }^{\mathrm{c}}$ & $\mathrm{Mg}_{\mathrm{AA}}{ }^{\mathrm{c}}$ & $\mathrm{Cu}_{\mathrm{AA}}{ }^{\mathrm{d}}$ & $\mathrm{Co}_{\mathrm{AA}}{ }^{\mathrm{d}}$ & $\mathrm{Cu}_{\mathrm{CaCl} 2}^{\mathrm{d}}$ & $\mathrm{Co}_{\mathrm{CaCl} 2}^{\mathrm{d}}$ \\
\hline A & 0 & 0 & $3.7 \pm 0.1 c$ & $4.1 \pm 0.1 d$ & $2.87 \pm 0.23 a$ & $2.2 \pm 1.65 b$ & $8.17 \pm 1.8 b$ & $21.5 \pm 1.1 \mathrm{~d}$ & $2.60 \pm 0.00 c$ & $0.42 \pm 0.22 c$ & $1.4 \pm 0.04 b$ \\
\hline$A+S D B$ & 8342 & 311 & $4.2 \pm 0.0 \mathrm{~b}$ & $4.6 \pm 0.0 \mathrm{~b}$ & $2.37 \pm 0.64 a$ & $0.97 \pm 1.5 b$ & $2.3 \pm 0.26 c$ & $3063 \pm 57 a$ & $2.67 \pm 0.15 c$ & $380 \pm 14.2 \mathrm{a}$ & $2.1 \pm 0.14 b$ \\
\hline $\mathrm{A}+\mathrm{RSC}$ & 28 & 56 & $3.7 \pm 0.1 c$ & $4.2 \pm 0.1 \mathrm{~cd}$ & $2.78 \pm 0.08 \mathrm{a}$ & $2.3 \pm 0.15 b$ & $6.77 \pm 1.3 b$ & $19.4 \pm 1.2 \mathrm{~d}$ & $5.37 \pm 1.8 \mathrm{~b}$ & $0.15 \pm 0.13 c$ & $2.8 \pm 0.93 b$ \\
\hline $\mathrm{A}+\mathrm{RSCmin}$ & 1328 & 100 & $3.8 \pm 0.0 \mathrm{c}$ & $4.2 \pm 0.0 \mathrm{~cd}$ & $2.96 \pm 0.09 a$ & $3.6 \pm 1.02 b$ & $9.37 \pm 1.4 b$ & $297 \pm 24 c$ & $14.8 \pm 1.0 \mathrm{a}$ & $14.6 \pm 1.6 c$ & $9.7 \pm 1.88 \mathrm{a}$ \\
\hline $\mathrm{A}+\mathrm{RSF}$ & 5609 & 227 & $3.9 \pm 0.0 c$ & $4.3 \pm 0.1 c$ & $2.75 \pm 0.10 \mathrm{a}$ & $1.9 \pm 0.36 b$ & $7.5 \pm 1.25 b$ & $945 \pm 9.5 b$ & $15.4 \pm 0.7 \mathrm{a}$ & $87.3 \pm 7.7 b$ & $11.4 \pm 1.2 \mathrm{a}$ \\
\hline A + DStrat & 843 & 27 & $5.6 \pm 0.2 \mathrm{a}$ & $5.7 \pm 0.1 \mathrm{a}$ & $2.78 \pm 0.17 a$ & $121 \pm 3.8 \mathrm{a}$ & $70.3 \pm 2.6 a$ & $286 \pm 29.5 c$ & $3.0 \pm 0.61 b c$ & $0.60 \pm 0.03 c$ & $0.3 \pm 0.06 b$ \\
\hline B & 0 & 0 & $4.0 \pm 0.0 \mathrm{e}$ & $4.5 \pm 0.0 \mathrm{e}$ & $0.26 \pm 0.01 \mathrm{a}$ & $0.10 \pm 0.0 \mathrm{~b}$ & $0.67 \pm 0.5 b$ & $3.17 \pm 0.57 \mathrm{e}$ & $0.60 \pm 0.0 \mathrm{~b}$ & $0.5 \pm 0.47 d$ & $0.24 \pm 0.0 \mathrm{~d}$ \\
\hline $\mathrm{B}+\mathrm{SDB}$ & 8342 & 311 & $4.8 \pm 0.0 \mathrm{~b}$ & $5.2 \pm 0.0 \mathrm{~b}$ & $0.24 \pm 0.02 \mathrm{a}$ & $0.3 \pm 0.26 b$ & $1.1 \pm 0.32 b$ & $2128 \pm 5 a$ & $1.9 \pm 0.06 b$ & $365 \pm 15.0 \mathrm{a}$ & $1.3 \pm 0.07 c$ \\
\hline $\mathrm{B}+\mathrm{RSC}$ & 28 & 56 & $4.0 \pm 0.0 \mathrm{e}$ & $4.2 \pm 0.1 \mathrm{e}$ & $0.30 \pm 0.06 a$ & $0.97 \pm 0.8 b$ & $1.27 \pm 0.6 b$ & $8.27 \pm 1.58 \mathrm{e}$ & $0.9 \pm 0.06 b$ & $0.4 \pm 0.12 \mathrm{~d}$ & $0.5 \pm 0.06 \mathrm{~cd}$ \\
\hline $\mathrm{B}+\mathrm{RSCmin}$ & 1328 & 100 & $4.1 \pm 0.1 \mathrm{~d}$ & $4.7 \pm 0.0 \mathrm{~d}$ & $0.23 \pm 0.02 \mathrm{a}$ & $0.10 \pm 0.0 \mathrm{~b}$ & $1.10 \pm 0.1 b$ & $314 \pm 17.3 c$ & $10.8 \pm 1.6 a$ & $108 \pm 5.6 c$ & $8.45 \pm 0.7 a$ \\
\hline $\mathrm{B}+\mathrm{RSF}$ & 5609 & 227 & $4.4 \pm 0.0 c$ & $5.0 \pm 0.0 c$ & $0.24 \pm 0.01 \mathrm{a}$ & $0.10 \pm 0.0 \mathrm{~b}$ & $1.50 \pm 0.2 b$ & $945 \pm 56.5 b$ & $10.3 \pm 0.3 a$ & $237 \pm 8.3 b$ & $7.15 \pm 0.4 b$ \\
\hline B + DStrat & 843 & 27 & $7.0 \pm 0.1 \mathrm{a}$ & $6.7 \pm 0.0 \mathrm{a}$ & $0.23 \pm 0.02 \mathrm{a}$ & $55.4 \pm 1.9 \mathrm{a}$ & $29.1 \pm 0.5 a$ & $205 \pm 9.3 d$ & $1.87 \pm 0.06 \mathrm{~b}$ & $0.14 \pm 0.1 \mathrm{~d}$ & $0.1 \pm 0.07 d$ \\
\hline
\end{tabular}

HF: triacid HF digestion (NF ISO11466), AA: $\mathrm{CH}_{3} \mathrm{COONH}_{4}-\mathrm{EDTA}$ at pH 4.65 (Faucon et al., 2009) and CaCl 2 : 0.01 mol/L CaCl 2 .

Different letters indicate a significant difference according to Tukey's-test at $p<0.05$.

a $\mathrm{mg}$.

b $\mathrm{g} / 100 \mathrm{~g}$.

c $\mathrm{mg} / 100 \mathrm{~g}$.

d $\mathrm{mg} / \mathrm{kg}$.

\subsection{Composition of lysimeter percolating solution}

The results of the lysimeter percolation study are presented in Table 3 for soil properties and Fig. 3 for the evolution of cumulated leaching. The leaching was calculated by multiplying the concentrations by the quantity of solution and rescaled to $\mathrm{mg}$ of the element per $\mathrm{kg}$ of soil. Regarding the concentrations of the solutions, the first important result to consider is that no significant difference in concentrations of $\mathrm{Cu}$ and $\mathrm{Co}$ in the percolating solutions (after $\log 10$ transformation) was found between the different sampling dates. Regarding differences between the A and B horizons and effects of rock, interactions were significant and conclusions depend on the element considered. Compared with the control soil, $\mathrm{Cu}$ concentrations in lysimeter solutions were higher for soils mixed with every rock except RSC, SDB presenting the largest concentrations. Differences between A and B were also found for the treatments with the smallest inputs of $\mathrm{Cu}$ (Control, RSC and DStrat). For Co, significant differences were found for SDB, RSF and RSCmin compared with other treatments, and solutions from B presented a mean concentration of Co $0.1 \mathrm{mg} / \mathrm{L}$ lower than A.

Regarding differences of cumulated leaching of elements (in $\mathrm{mg} / \mathrm{kg}$ of soil), significant differences were found for $\mathrm{Cu}$ between $\mathrm{A}$ and $\mathrm{B}$ at the end of the experiment for the control, RSC and DStrat (Fig. 3a and b), and among treatments, SDB, RSCmin and RSF were significantly different from the control, SDB being greatly higher than all the other rocks. For Co, leaching from B was significantly lower than from A, on the one side, and significantly higher for all treatments compared with the control (Fig. $3 \mathrm{c}$ and d). The decreasing order of metals release from rock can be estimated as follows: $\mathrm{SDB} \gg \mathrm{RSF} \geq \mathrm{RSCmin}>$ DStrat $\geq$ RSC for $\mathrm{Cu}$ and $\mathrm{SDB} \geq \mathrm{RSF} \geq \mathrm{RSCmin} \geq \mathrm{RSC} \geq$ DStrat for Co.

\subsection{Rocks' effect on soil physicochemical properties}

Miombo soil (considered as control) and soil mixed with the DStrat or RSC rocks present the lower $\mathrm{Cu}-\mathrm{Co}$ concentrations in lysimetric solutions, for $\mathrm{Cu}$ and $\mathrm{Co}$, respectively. Moderate concentrations were found in the soil mixed with the RSCmin for both metals. At the end of the experiment, the mixing of soils and rocks has generally changed the soil composition in certain elements and properties. Table 3 shows the individual mean values of the variables affected by the presence of rocky materials. It was found that the addition of the DStrat rock significantly increased $(p<0.01) \mathrm{pH}_{\mathrm{KCl}}$ by 2 to 3 units of $\mathrm{pH}$ according to the horizon. The effect of SDB, in both horizons, RSF and RSCmin rocks, in B, were also significant compared with the control soil (Table 3). It was also revealed that the DStrat rock significantly increased the available concentration of Ca (121 and $55.4 \mathrm{mg} / 100 \mathrm{~g}$ in A and B, respectively) and $\mathrm{Mg}$ (7.3 and $29.1 \mathrm{mg} / 100 \mathrm{~g}$, respectively) compared with the other rocks and the control soil (Table 3). Indeed, DStrat rock is mainly composed of dolomites whose weathering drives $\mathrm{Ca}$ and $\mathrm{Mg}$ mobility. These results are consistent with the analytical and mineralogical characterization of the rocks presented in Table 2 .

Regarding $\mathrm{Cu}$ and $\mathrm{Co}$, the soils showed an increase of available content proportional to the added amounts of these two elements 
a

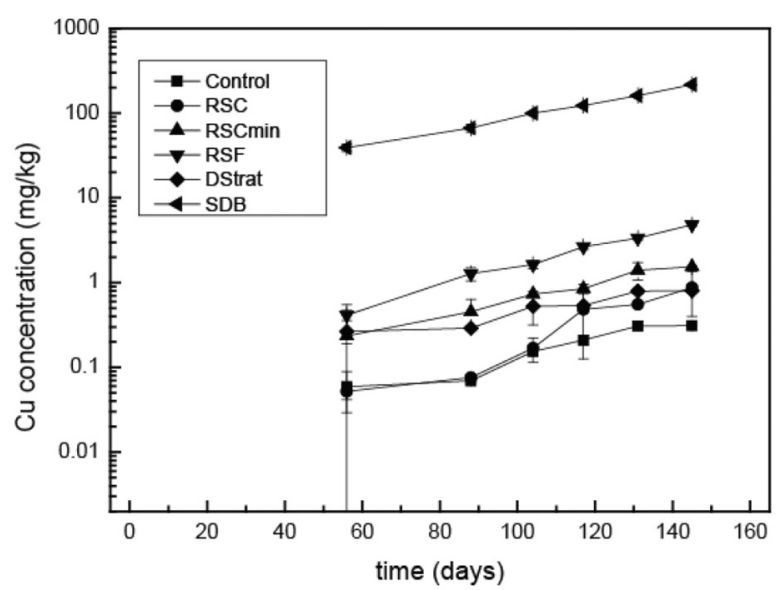

C

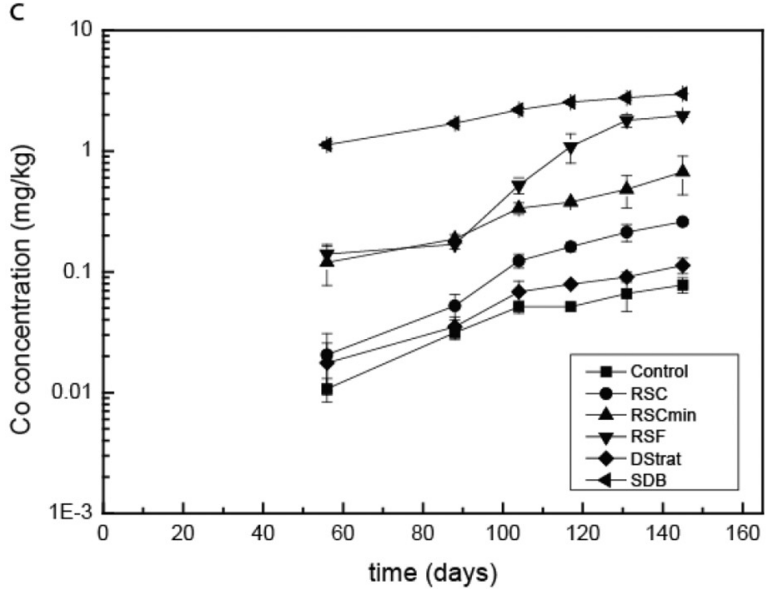

b

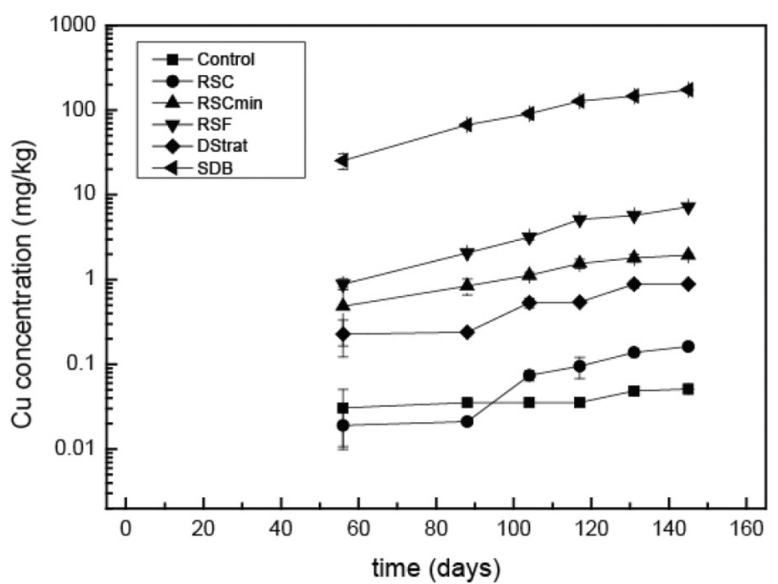

d

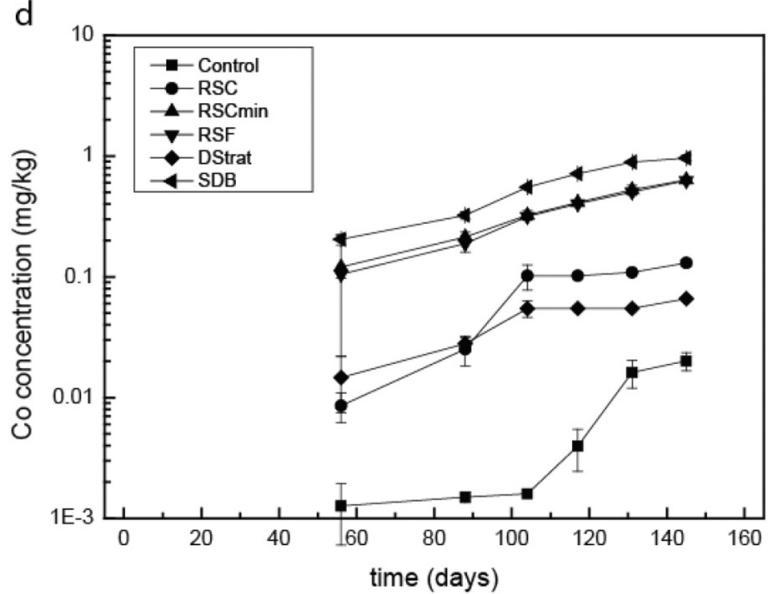

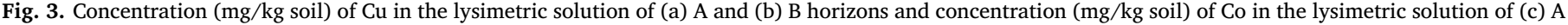
and (d) B horizons after mixing soil with mineralized rocks according to time (days). 60 days is the first sampling point.

(Table 3), with the exception of Co in SDB. The A and $\mathrm{B}$ horizons indeed showed an increase of $\mathrm{Cu}_{\mathrm{AA}}\left(\mathrm{CH}_{3} \mathrm{COONH}_{4}\right.$-EDTA) content following the order (inputs in $\mathrm{mg} / \mathrm{kg}$ in brackets): $\mathrm{T}(0)=\mathrm{RSC}(28)<$ Dstrat $(843) \leq \mathrm{RSCmin}(1328)<\mathrm{RSF}(5609)<\mathrm{SDB}(8342)$ while for Co the order is $\mathrm{T}(0)=$ Dstrat $(27)=\mathrm{SDB} \quad(311) \leq \mathrm{RSC}(56)<\mathrm{RSCmin}$ $(100)=\mathrm{RSF}$ (227). The $\mathrm{CaCl}_{2}$ contents reflect the effects of the total quantities of elements and of solubility of minerals which depends e.g. on $\mathrm{pH}$. For $\mathrm{Cu}$ and $\mathrm{Co}, \mathrm{RSC}$ and DStrat were both found to be similar to unamended control soil despite large differences of applied $\mathrm{Cu}$ and $\mathrm{Co}$. $\mathrm{SDB}, \mathrm{RSCmin}$ and RSF treatments produced a large increase of soluble $\mathrm{Cu}$ compared with the control, while the effect on soluble Co was mainly due to RSCmin and RSF.

\subsection{Sorption of $\mathrm{Cu}$ and $\mathrm{Co}$ by $\mathrm{A}$ and $\mathrm{B}$ soils horizons from Miombo woodlands}

Copper and Co sorptions were tested in A and B soil horizons from the same normal soil under Miombo as in the previous experiment. The ratio between the concentration of the compound remaining in solution $(C)$ and adsorbed on the solid $(Q)$ decreased when the solute concentration increased, providing concave curves (Fig. 4). As proposed by Limousin et al. (2007), it suggests a progressive saturation of the solid. The amounts of $\mathrm{Cu}$ sorbed by the A horizon were 10 times higher than those sorbed by the B horizon of the same soil (Fig. 4a and b). At the same time, the sorption capacity of Co was seven times higher in the A horizon than in the B (Fig. $4 \mathrm{c}$ and d). The sorption of $\mathrm{Cu}$ is better represented by the Freundlich than by the Langmuir isotherms according to the minimization of the residual sums of squares, whereas sorption of Co is better represented by the Langmuir isotherm. $\mathrm{Cu}$ is more sorbed in both horizons than $\mathrm{Co}$; the amounts of sorbed $\mathrm{Cu}$ in soils of the two horizons were 10 times higher than those of Co for the same horizons. This result means that Co should be more mobile and susceptible to migration in the soil profiles than $\mathrm{Cu}$, or would also be potentially more available for soil organisms than $\mathrm{Cu}$. This also indicates that the mobility of elements is bigger once they leave the A horizon.

\subsection{Influence of $\mathrm{pH}$ and $\mathrm{OM}$ on soluble $\mathrm{Cu}$ in soil contaminated by $\mathrm{CuSO}_{4}$ and $\mathrm{CuCO}_{3}$}

In this study, the addition of lime and compost significantly decreased the soluble $\mathrm{Cu}$ fraction of the soil previously contaminated by $\mathrm{CuCO}_{3}$ and $\mathrm{CuSO}_{4}$ (Fig. 5; Table 4). Compared with the control soil, the addition of $\mathrm{CuSO}_{4}$-acidified soil simultaneously increased the soluble $\mathrm{Cu}$ fraction. On the other hand, the addition of $\mathrm{CuCO}_{3}$ decreased soil acidity and increased soluble $\mathrm{Cu}$. Soluble $\mathrm{Cu}$ concentration in soil that received $\mathrm{Cu}$ as sulfate has thus substantially increased compared with those that received the $\mathrm{CuCO}_{3}$. Lime and compost additions were always accompanied by a decrease of acidity in the amended soils (Table 4). The addition of lime or compost strongly decreased the soluble fraction of $\mathrm{Cu}$ in contaminated soils as well. In the $\mathrm{CuCO}_{3}$-contaminated soil, a large decrease in concentrations of soluble $\mathrm{Cu}$ was observed, reaching values close to those of uncontaminated control soil $(\mathrm{Cu}=0.56 \mathrm{mg} / \mathrm{kg})$ in soil having received the highest dose of compost $(\mathrm{Cu}=2.68 \mathrm{mg} / \mathrm{kg})$ and especially the higher dose of lime 
a

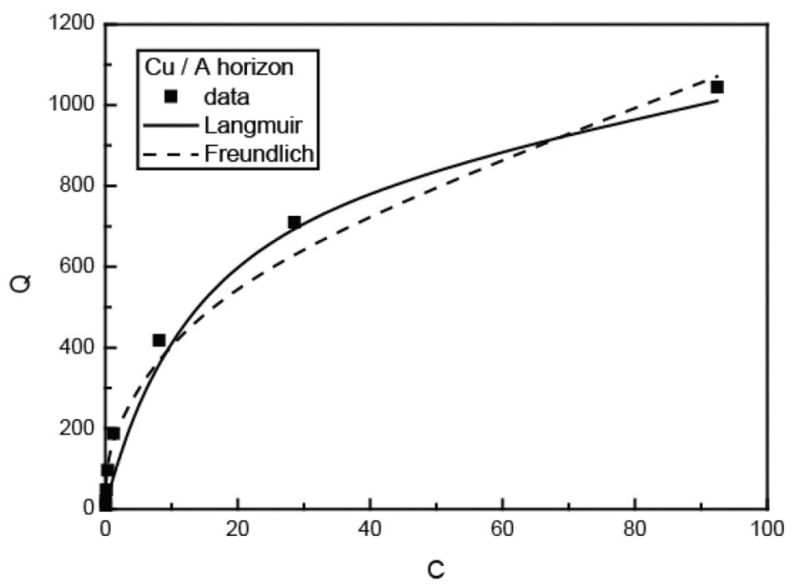

C

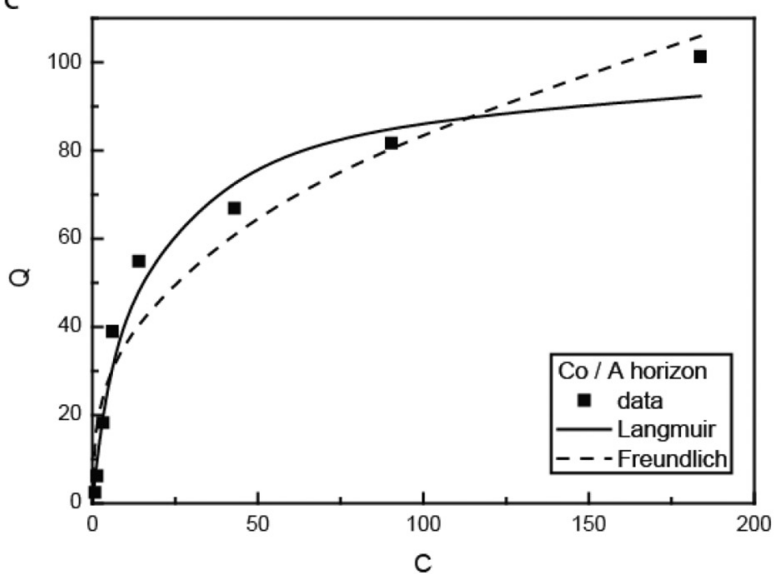

b

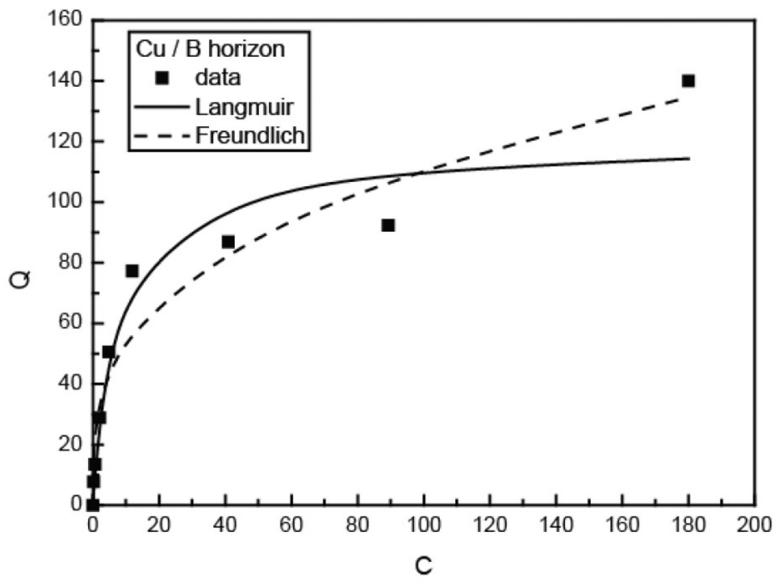

d

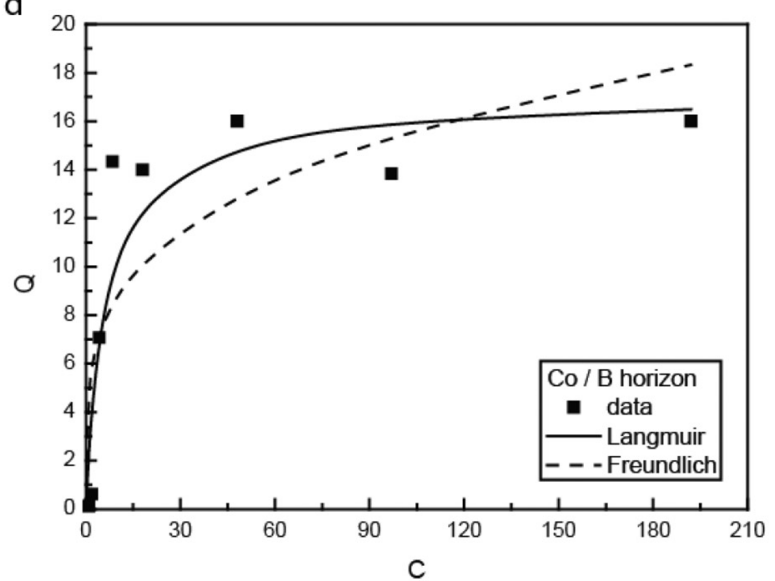

Fig. 4. Langmuir and Freundlich isotherms of $\mathrm{Cu}$ and $\mathrm{Co}$ in the $\mathrm{A}$ and $\mathrm{B}$ horizons of normal soil from Miombo woodland.

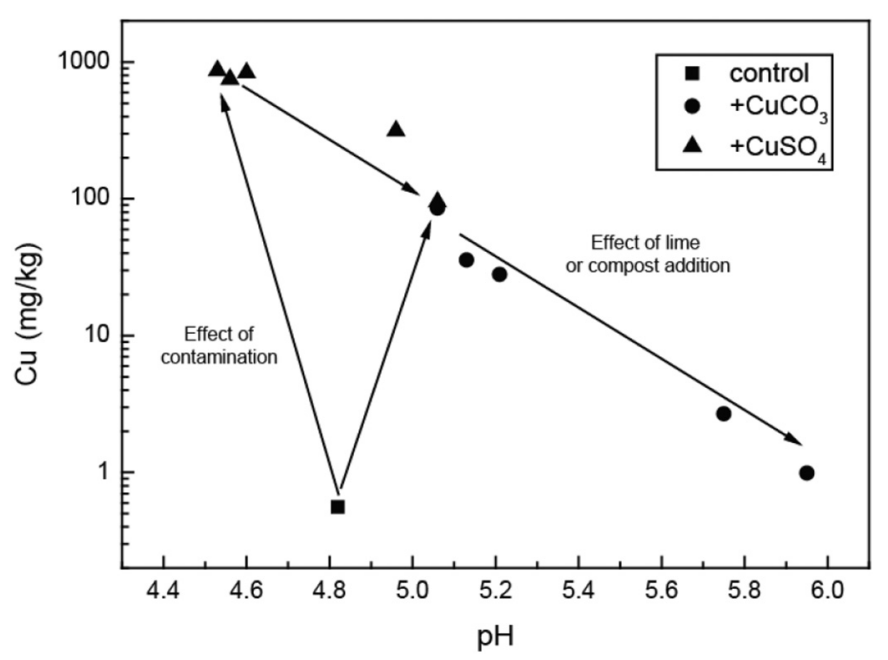

Fig. 5. Extractable $\mathrm{Cu}$ concentrations in the soil after the incubation experiment. The reference soil $(\mathrm{T}=\mathrm{Ref})$ was contaminated with $\mathrm{CuCO}_{3}$ or $\mathrm{CuSO}_{4}$ and received lime or compost amendments at two levels each.

$(\mathrm{Cu}=0.99 \mathrm{mg} / \mathrm{kg})$. According to Lange et al. (2016), Cu mobility is mainly influenced by OM in soils. Indeed, increasing organic compost did enhance a decrease of $\mathrm{Cu}$ solubility. OM is known to have a strong affinity for $\mathrm{Cu}$ due to its strong capacity to form chelate complexes with
$\mathrm{Cu}$ (Ponthieu et al., 2016). However, in this experiment, the addition of compost was also accompanied by an increase of soil $\mathrm{pH}_{\mathrm{CaCl} 2}$ compared with the contaminated unamended soil (Fig. 5). Soils that received $\mathrm{Cu}$ either in sulfate or carbonate forms showed a unique linear relationship between soluble $\mathrm{Cu}$ and $\mathrm{pH}$, with a significant negative correlation; $r=-0.988(p<0.001)$. The $\mathrm{pH}$ seems here to be the major factor in solubility and the apparent effect of $\mathrm{OM}$ is due to the effect on reducing acidity.

\section{Discussion}

\subsection{Mineralogy controls the supply of elements}

The results of this study give evidence that the nature of the rocks used in the experiment had a significant impact on the quantity of $\mathrm{Cu}$ and Co in the percolating solution and in the soil at the end the experiment. This behaviour is explained by a chemical and mineralogical composition that reflects sensitivity to physical and chemical weathering. The mineralogical aspect is essential to take into account in assessing the potential mobility of TEs (García-Lorenzo et al., 2014).

In our results, the SDB rocks showed the highest amounts of leached $\mathrm{Cu}$ and $\mathrm{Co}$ as well as the highest quantities of $\mathrm{CaCl}_{2^{-}}$or $\mathrm{CH}_{3} \mathrm{COONH}_{4}$-EDTA-extractable $\mathrm{Cu}$ in soils. Relationships between the mobility of $\mathrm{Cu}$ and $\mathrm{Co}$ from solid phases to soil solution and chemical extractions were shown among others by Collins and Kinsela (2011), Mpundu Mubemba et al. (2014) and Pourret et al. (2015). Rock weathering involves physical and chemical breakdown of minerals, the 
Table 4

Influence of lime and compost on the soluble fraction of $\mathrm{Cu}$ in contaminated soil $(\mathrm{mg} / \mathrm{kg})$.

\begin{tabular}{|c|c|c|c|c|c|c|c|c|c|c|c|}
\hline & \multirow{2}{*}{$\begin{array}{l}\text { Control } \\
\mathrm{T}\end{array}$} & \multicolumn{5}{|c|}{$\mathrm{CuCO}_{3}$} & \multicolumn{5}{|c|}{$\mathrm{CuSO}_{4}$} \\
\hline & & TCO & TCC1 & TCC2 & TCM1 & TCM2 & TSO & TSC1 & TSC2 & TSM1 & TSM2 \\
\hline $\mathrm{pH}_{\mathrm{CaCl} 2}$ & 4.82 & 5.06 & 5.13 & 5.95 & 5.21 & 5.75 & 4.53 & 4.56 & 4.96 & 4.60 & 5.06 \\
\hline $\mathrm{Cu}_{\mathrm{CaCl} 2}{ }^{\mathrm{a}}$ & 0.56 & 85.6 & 35.7 & 0.99 & 28.1 & 2.68 & 867 & 749 & 315 & 836 & 95 \\
\hline $\mathrm{Cu}_{\text {total }}{ }^{\mathrm{a}}$ & 118 & 3412 & 2674 & 3649 & 3177 & 3280 & 2613 & 2639 & 2600 & 2361 & 2338 \\
\hline
\end{tabular}

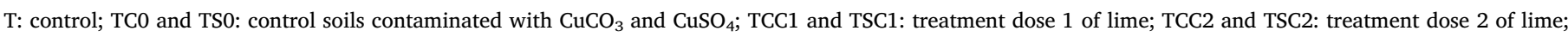
TCM1 and TSM1: treatment dose 1 of compost; TCM2 and TSM2: treatment dose 2 of compost.

${ }^{\text {a }} \mathrm{mg} / \mathrm{kg}$.

release of some of their constituent elements in soluble forms and the formation of secondary minerals through chemical reactions between weathering products (Alloway, 1995).

Siliceous rocks (RSF, RSCmin and RSC) are more resistant to weathering than those derived from dolomitic shales (SDB) or laminated dolomites (DStrat). The SDB has, besides its mineralogy, the highest concentration in $\mathrm{Cu}$ (Table 2) as sulfides (bornite, carrollite), that allow it to release the largest amounts of $\mathrm{Cu}$ during its weathering. It was also found in this study that release of elements by siliceous rocks in soil solution was generally limited because of the low solubility of minerals formed under the present weathering conditions. Finally, weakly mineralized RSC (with cuprite) showed levels of concentrations of soil-soluble metals or in lysimetric solution close to that of the control unamended soil.

The mineralogy and chemical composition, as well as their total $\mathrm{Cu}$ and Co concentrations, explain the observed differences in behaviour between the rocks used in the experiments. Trace metal mobility is generally low in the weathering process (Daldoul et al., 2015; Sverdrup, 1990). This situation may be explained by the controlled conditions of the experiment in favour of higher reactions between rocks, soil water and soil compounds. The presence of $\mathrm{Cu}$ and $\mathrm{Co}$ as stable compounds such as malachite and heterogenite as suggested by Decrée et al. (2015), De Putter et al. (2010) and Pourret et al. (2016) could also explain this low $\mathrm{Cu}$ and Co mobility (Fig. 6).

\section{2. $p H$ controls the solubility}

The solubility of elements in soils is influenced by many factors, including pH (e.g. Cappuyns and Swennen, 2008; Hooda, 2010), redox state, macronutrient content, available water content and temperature (Alloway, 1995). In a simple system, without inorganic or organic ligands, soluble forms of metals will depend more on $\mathrm{pH}$ (Adriano et al., 2004) and the redox status of the soil. Indeed, the degree of metal mobilization towards soil solution is favoured by acidity (KabataPendias, 2010). pH variation induces electrical charges around certain soil components. Thus, the increase in $\mathrm{pH}$ enhances the density of negative charges on the surfaces and the negative electrical potential on the main sorption sites; this will enhance the precipitation of iron and manganese oxyhydroxides and aluminium oxides (Table 2). Overall, the dissolution dynamics of metal-bearing particles deposited into soils is highly dependent on their mineralogical composition and soil pH (e.g. Pourret et al., 2016). Copper and Co are dominantly present as relatively stable compounds, such as malachite and heterogenite (Table 2). The stability field for malachite is highlighted in Fig. 6, which shows that malachite is stable in oxidizing conditions and neutral to alkaline $\mathrm{pH}$ (conditions occurring in the sampling sites). A pH decrease will enhance $\mathrm{Cu}$ mobility (i.e. as $\mathrm{Cu}^{2+}$ ).

The importance of $\mathrm{pH}$ in this study is highlighted by the strong correlation between the free cations in solution and the $\mathrm{pH}$ of the same solution (Table 3; Figs. 5 and 6) as previously observed by KabataPendias (2010). The distribution of $\mathrm{Cu}$ and Co in soil solution is determined by the pH (Adriano, 2001) and OM (Impellitteri et al., 2001). The low concentrations of $\mathrm{Cu}$ and $\mathrm{Co}$ in lysimetric solutions in soil

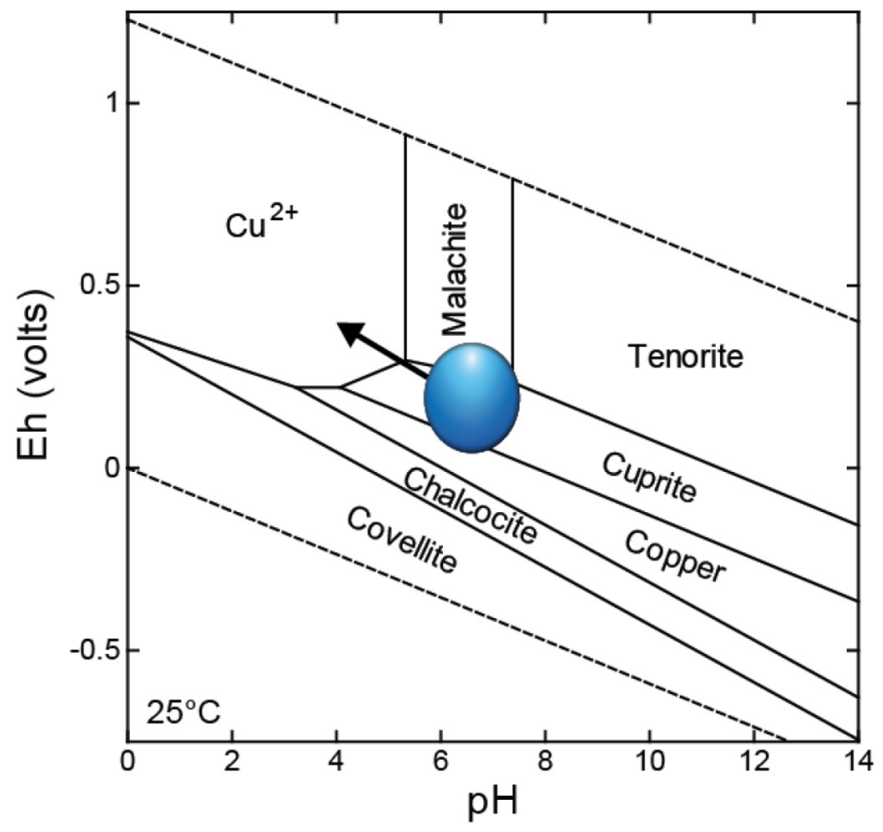

Fig. 6. Eh-pH stability diagram of $\mathrm{Cu}$ minerals and dissolved species at $25{ }^{\circ} \mathrm{C}$ with $\left[\mathrm{Cu}^{2+}\right] 10^{-4} \mathrm{~mol} / \mathrm{L}, \mathrm{P}_{\mathrm{CO} 2} 10^{-2} \mathrm{~mol} / \mathrm{L}$ and $200 \mathrm{mg} / \mathrm{L} \mathrm{SO}_{4}{ }^{2-}$ (modified from Pourret et al., 2016). The blue circle highlights the conditions of the sampled sites and the black arrow the weathering trend. (For interpretation of the references to colour in this figure legend, the reader is referred to the web version of this article.)

mixed with DStrat rock and the relationship between soluble $\mathrm{Cu}$ in soil contaminated by $\mathrm{CuCO}_{3}$ and $\mathrm{CuSO}_{4}$ and pH show how the latter is effective in regulating the availability or the mobility of metals in the soil (Table 3, Figs. 3 and 5).

The increase in $\mathrm{pH}$ and exchangeable $\mathrm{Ca}$ and $\mathrm{Mg}$ in the experiments significantly reduced soluble $\mathrm{Cu}$ and $\mathrm{Co}$ in the soil. Consequently, their mobility and toxicity decreased at the same time. The presence of dolomite in the DStrat rock has contributed significantly to the precipitation and sorption of $\mathrm{Cu}$ and $\mathrm{Co}$ in soils that received this rock (Tables 2 and 3). This explains why in some agrosystem treatments, Ca and $\mathrm{Mg}$ are added to soil as lime or dolomite to improve fertility and to reduce the acidity and element mobility (Fageria and Baligar, 2008). Indeed, the presence of carbonate ions in soils increases their buffering capacity against pH decrease (Du Laing et al., 2009).

Copper addition as sulfate and carbonate forms has affected the soil properties differently. The application of $\mathrm{CuSO}_{4}$ tends to increase the soil acidity; however, the addition of $\mathrm{CuCO}_{3}$ decreases it (Shutcha et al., 2010). The differences of soil reactions generated by the dissolution of $\mathrm{CuSO}_{4}$ or $\mathrm{CuCO}_{3}$ in soil water can be explained by the differences of behaviour of anions in water linked to the strength of sulfuric and carbonic acids.

The experiment conducted in the laboratory on the sorption of $\mathrm{Cu}$ and $\mathrm{Co}$ in the A and B horizons of Miombo soil showed clearly the 
effectiveness of organic and mineral horizons to retain these two metals (Fig. 4). Moreover, liming action has demonstrated the effectiveness of the amendment in mitigating the mobility and bioavailability of $\mathrm{Cu}$ and Co. The increase in $\mathrm{pH}$ by liming would increase the negative charges of soil constituents (Sparks, 2013). The lime and the particulate OM are effective remedies to mitigate the migration of the metallic elements in contaminated and acidic soils.

\subsection{Organic matter controls the mobility of metals}

The importance of OM on the behaviour and fate of trace metals in soils has been demonstrated by several authors (Liénard et al., 2014; Liénard and Colinet, 2016; Mohamed et al., 2010; Ponthieu et al., 2016). The application of OM contributes to changes in soil pH (Karaca, 2004) and to increasing the soil retention of metallic elements (Mohamed et al., 2010). In our experiment with lysimeters, OM (A horizon compared with B horizon of Miombo) did not seem to contribute effectively to retention of $\mathrm{Cu}$ and $\mathrm{Co}$ in soil mixed with mineralized rocks. The result indeed shows equal or higher rates of leaching for the A than for the B horizon. On the other hand, the sorption experiment shows higher retention potential for the A horizon. If we consider the properties of the soils from lysimeters at the end of the experiment, it can be seen that the A horizon has been subjected to a much more pronounced acidification than the B horizon. This change of soil $\mathrm{pH}$ probably explains why leaching was higher under the A horizon than under the $\mathrm{B}$ horizon. The soil acidification could indeed reduce the $\mathrm{Cu}$ and $\mathrm{Co}$ sorption capacity and therefore contribute to the transport of $\mathrm{Cu}$ and $\mathrm{Co}$ in deeper horizon. However, the particulate OM has probably gone through a partial microbial degradation leading to the release of dissolved $\mathrm{OM}$ involved in the transport of $\mathrm{Cu}$ and $\mathrm{Co}$ in deeper horizon. The acidification could be linked to a higher mineralization of $\mathrm{OM}$ but this is not validated by measurement of OM content before and after the experiment.

Still, the action of OM goes far beyond soil; it also affects the weathering of mineralized rocks (Drever and Stillings, 1997). Some organic acids such as oxalic acid, for example, appear to speed up the dissolution of feldspar (a silicate mineral) by complexing $\mathrm{Al}$ ions on the surface, while the humic acids do not seem to affect its dissolution rate (Drever and Stillings, 1997). According to these authors, in a system where the balance soil-solution is far from being achieved, the effect of organic acids on weathering rate does not allow an understanding of these processes of dissolution.

However, in the laboratory experiment on the sorption of $\mathrm{Cu}$ and $\mathrm{Co}$ by the horizons, it was found that a marked difference of the $\mathrm{Cu}$ and $\mathrm{Co}$ sorption takes place between the OM-rich and OM-poor horizons (Fig. 4). In both horizons, $\mathrm{Cu}$ is better adsorbed by soils than Co. Copper affinity for OM (Adriano, 2001; Lange et al., 2014; Ponthieu et al., 2016) is far higher than that of Co. These statements explain the low retention of $\mathrm{Co}$ on the organic soil horizon studied compared with $\mathrm{Cu}$ (Pourret et al., 2015).

In the soils contaminated with $\mathrm{CuSO}_{4}$ and $\mathrm{CuCO}_{3}$ and then amended with compost, it was observed that the increase in $\mathrm{pH}$ in soils could be explained by the complexation of aluminium ions (originating from the weathering of aluminosilicates) by OM that would therefore neutralize the acidity of the $\mathrm{Al}$ by lowering its activity in solution (Drever and Stillings, 1997). Besides, the decrease of soluble Cu observed in this soil might partly be explained by the high retention capacity of added compost. By combining with OM, metal cations are immobilized in the soil; increasing the humic fraction and the aromaticity of OM promote the complexation of metal ions (Mueller et al., 2012).

Batch sorption experiments give only partial insights of processes occurring during the lysimeter study. They show that retention potential differs according to soil properties and that it is linked to content of organic matter and cationic exchange capacity but also to the cation considered. Incubation reactions compare the influence of the anion associated to $\mathrm{Cu}$ and results show that $\mathrm{pH}$ resulting from dissolution of salts is the key factor to control mobility of the studied metal. During the long term experiments, soil properties vary in time and space and actual processes should differ from potential. Small-scale organisation of soil constituents and porosity affect both exchange and solubilisation reactions occurring such as the variations of conditions of temperature and water content do. Our experiments showed that the influence of soil horizon on $\mathrm{Cu}$ and $\mathrm{Co}$ retention was mainly marked for small rates of dissolution, while for rocks such as SBD the quantities of studied metals brought to soil solution were probably exceeding the retention capacity of soil for both types of horizon.

\section{4. $\mathrm{CaCl}_{2}$-extractable $\mathrm{Cu}$ and $\mathrm{Co}$ is a good assessment of mobility}

The assessment of the soluble concentration of $\mathrm{Cu}$ and $\mathrm{Co}$ showed a linear relationship with the $\mathrm{pH}$ of the solution and with the available fraction of these two metals (Fig. 4; Table 4). A negative relationship was obtained with the soluble extractable concentrations with $0.01 \mathrm{~mol} / \mathrm{L} \mathrm{CaCl}_{2}$. The $\mathrm{pH}$ increase is inversely proportional to that of the soluble fraction and thus to mobility and bioavailability of metals in the soil solution. This reagent has been appreciated by many authors for its effectiveness in estimating the soluble fraction and the available metallic elements in soils, and also allows prediction of the soluble elements and assimilation by plants (Collins and Kinsela, 2011; Feng et al., 2005). Indeed, neutral salts are considered (e.g. $\mathrm{CaCl}_{2}$ ) as adequate extractives in the assessment of impacts of contaminant on plants and the soil biological activities (Kabata-Pendias, 2004).

In addition, speciation modelling (Muyumba et al., 2018; Ponthieu et al., 2016; Pourret et al., 2015) has also shown encouraging results in the assessment of the mobility of TEs in soils. These approaches, in addition to those obtained in this study; provide interesting tools in assessing the risks of contamination of TEs in the environment.

\section{Conclusion}

This study aimed to progress in the understanding of the processes affecting the mobility of $\mathrm{Cu}$ and $\mathrm{Co}$ in the natural ecosystems of copper hills and sites contaminated by mining activities in Katanga. Experiments were conducted to assess the potential contribution of $\mathrm{Cu}$ and $\mathrm{Co}$ rich rocks to the soil content and to evaluate the mobility of $\mathrm{Cu}$ and Co released into the soil solution according to the properties of soils.

The lysimeter study allowed measurement of the leaching of $\mathrm{Cu}$ and Co under semi-controlled conditions; two additional studies under laboratory conditions gave insight into the effect of soil reaction and OM content on metal solubility and sorption on solid phases.

The studied rocks showed differences in mineralogical and total $(\mathrm{Cu}$, $\mathrm{Co}, \mathrm{Fe}$ and $\mathrm{Al}$ ) composition. The $\mathrm{Cu}$-bearing phases were sulfides (SDB), oxides (RSC, RSF, DStrat) and carbonates (RSF, DStrat), which are known to present different solubility. Moreover, the siliceous rocks (RSF, RSCmin and RSC) are more resistant to weathering than those derived from dolomitic shales (SDB) or laminated dolomites (DStrat). Beside the solubility of minerals, the total content in element is a crucial factor of soil and soil solution contamination. It was found from sorption and incubation experiments that $\mathrm{pH}$ and $\mathrm{OM}$ content were also important factors regarding mobility of $\mathrm{Cu}$ in soils. Hence, it can be stated that mineralogical composition, trace metal concentration and soil properties all explained the content of $\mathrm{Cu}$ and $\mathrm{Co}$ in the lysimeter solutions.

The impact of contamination from mine tailings or mineralized rock rich in $\mathrm{Cu}$-Co minerals should be considered as a real danger of transfer from metallic solid particles to soils and soil solutions, which may affect biological organisms in the soil or quality of surface and ground-water. Not only total content but also the mineralogical nature of the solid particles and their reactivity should be an important factor to consider in the implementation of remediation initiatives or for the conservation of metallophytes. Taking into account the soil conditions, total and 
specific forms of the element concerned, soil OM content should help to understand and predict the fate of TEs in contaminated ecosystems. The counteranion associated to $\mathrm{Cu}$ in the incubation experiment affected the soil $\mathrm{pH}$ and hence soluble concentrations of $\mathrm{Cu}$. The addition of particulate $\mathrm{OM}$ and lime significantly modified soil $\mathrm{pH}$ and reduced the mobility of $\mathrm{Cu}$ and $\mathrm{Co}$ in the soil. The control of soil reaction and organic content seem to be the most efficient ways to manage $\mathrm{Cu}$ and $\mathrm{Co}$ behaviour in soil-plant systems, whatever the objective of land use/ management.

\section{References}

Adriano, D.C., 2001. Trace Elements in Terrestrial Environments: Biogeochemistry, Bioavailability and Risks of Metals. Springer New York.

Adriano, D.C., Wenzel, W.W., Vangronsveld, J., Bolan, N.S., 2004. Role of assisted natural remediation in environmental cleanup. Geoderma 122, 121-142.

Alloway, B.J., 1995. Heavy Metals in Soils, 2nd ed. Blackie Academic and Professional, London.

Banza, C.L.N., Nawrot, T.S., Haufroid, V., Decrée, S., De Putter, T., Smolders, E., Kabyla, B.I., Luboya, O.N., Ilunga, A.N., Mutombo, A.M., Nemery, B., 2009. High human exposure to cobalt and other metals in Katanga, a mining area of the Democratic Republic of Congo. Environ. Res. 109, 745-752.

Cailteux, J.L.H., Kampunzu, A.B., Lerouge, C., Kaputo, A.K., Milesi, J.P., 2005. Genesis of sediment-hosted stratiform copper-cobalt deposits, central African Copperbelt. J. Afr. Earth Sci. 42, 134-158.

Cappuyns, V., Swennen, R., 2008. The use of leaching tests to study the potential mobilization of heavy metals from soils and sediments: a comparison. Water Air Soil Pollut. 191, 95-111.

Collins, R.N., Kinsela, A.S., 2010. The aqueous phase speciation and chemistry of cobalt in terrestrial environments. Chemosphere 79, 763-771.

Collins, R.N., Kinsela, A.S., 2011. Pedogenic factors and measurements of the plant uptake of cobalt. Plant Soil 339, 499-512.

Daldoul, G., Souissi, R., Souissi, F., Jemmali, N., Chakroun, H.K., 2015. Assessment and mobility of heavy metals in carbonated soils contaminated by old mine tailings in North Tunisia. J. Afr. Earth Sci. 110, 150-159.

De Putter, T., Mees, F., Decrée, S., Dewaele, S., 2010. Malachite, an indicator of major Pliocene $\mathrm{Cu}$ remobilization in a karstic environment (Katanga, Democratic Republic of Congo). Ore Geol. Rev. 38, 90-100.

Decrée, S., Deloule, E., Ruffet, G., Dewaele, S., Mees, F., Marignac, C., Yans, J., de Putter, T., 2010. Geodynamic and climate controls in the formation of Mio-Pliocene worldclass oxidized cobalt and manganese ores in the Katanga province, DR Congo. Mineral. Deposita 45, 621-629.

Decrée, S., Pourret, O., Baele, J.-M., 2015. Rare earth element fractionation in heterogenite $(\mathrm{CoOOH})$ : implication for cobalt oxidized ore in the Katanga Copperbelt (Democratic Republic of Congo). J. Geochem. Explor. 159, 290-301.

Drever, J.I., Stillings, L.L., 1997. The role of organic acids in mineral weathering. Colloids Surf. A 120, 167-181.

Du Laing, G., Rinklebe, J., Vandecasteele, B., Meers, E., Tack, F.M.G., 2009. Trace metal behaviour in estuarine and riverine floodplain soils and sediments: a review. Sci. Total Environ. 407, 3972-3985.

Duvigneaud, P., 1958. La végétation du Katanga et de ses sols métallifères. Bull. Soc. R. Bot. Belg. 90, 127-286.

Fageria, N.K., Baligar, V.C., 2008. Ameliorating soil acidity of tropical oxisols by liming for sustainable crop production. Adv. Agron. 99, 345-399.

Faucon, M.P., Colinet, G., Mahy, G., Ngongo Luhembwe, M., Verbruggen, N., Meerts, P., 2009. Soil influence on $\mathrm{Cu}$ and $\mathrm{Co}$ uptake and plant size in the cuprophytes Crepidorhopalon perennis and C. tenuis (Scrophulariaceae) in SC Africa. Plant Soil 317, 201-212.

Faucon, M.P., Parmentier, I., Colinet, G., Mahy, G., Luhembwe, M.N., Meerts, P., 2011 May rare metallophytes benefit from disturbed soils following mining activity? The case of the Crepidorhopalon tenuis in Katanga (D. R. Congo). Restor. Ecol. 19, 333-343.

Faucon, M.P., Chipeng, F., Verbruggen, N., Mahy, G., Colinet, G., Shutcha, M., Pourret, O., Meerts, P., 2012. Copper tolerance and accumulation in two cuprophytes of South Central Africa: Crepidorhopalon perennis and C. tenuis (Linderniaceae). Environ. Exp. Bot. $84,11-16$.

Faucon, M.-P., Le Stradic, S., Boisson, S., Ilunga wa Ilunga, E., Séleck, M., Lange, B., Guillaume, D., Shutcha, M.N., Pourret, O., Meerts, P., Mahy, G., 2016. Implication of plant-soil relationships for conservation and restoration of copper-cobalt ecosystems. Plant Soil 403, 153-165.

Fay, I., Barton, M.D., 2012. Alteration and ore distribution in the Proterozoic Mines Series, Tenke-Fungurume Cu-Co district, Democratic Republic of Congo. Mineral. Deposita 47, 501-519.

Feng, M.H., Shan, X.Q., Zhang, S., Wen, B., 2005. A comparison of the rhizosphere-based method with DTPA, EDTA, CaCl2, and NaNO3 extraction methods for prediction of bioavailability of metals in soil to barley. Environ. Pollut. 13, 231-240.

García-Lorenzo, M.L., Pérez-Sirvent, C., Molina-Ruiz, J., Martínez-Sánchez, M.J., 2014 Mobility indices for the assessment of metal contamination in soils affected by old mining activities. J. Geochem. Explor. (Part B), 117-129.

Hooda, P.S., 2010. Trace Elements in Soils. Wiley, London.

ICDD, 2003. JCPDS PDF-2 Database. ICDD, Newton Square, PA, U.S.A.

Ilunga wa Ilunga, E., Séleck, M., Colinet, G., Faucon, M.-P., Meerts, P., Mahy, G., 2013.
Small-scale diversity of plant communities and distribution of species niches on a copper rock outcrop in Upper Katanga, D.R. Congo. Plant Ecol. Evol. 146, 173-182.

Impellitteri, C.A., Allen, H.E., Yin, Y., You, S.-J., Saxe, J.K., 2001. Soil properties controlling metal partitioning. In: Selim, H.M., Sparks, D.L. (Eds.), Heavy Metals Release in Soils, pp. 149-165.

IUSS Working Group WRB, 2015. World Reference Base for Soil Resources 2014, update 2015. International soil classification system for naming soils and creating legends for soil maps. In: World Soil Resources Reports No. 106. FAO, Rome.

Kabata-Pendias, A., 2004. Soil-plant transfer of trace elements-an environmental issue. Geoderma 122, 143-149.

Kabata-Pendias, A., 2010. Trace Elements in Soils and Plants, fourth edition. CRC Press, Boca Raton, FL, USA.

Kampunzu, A.B., Cailteux, J.L.H., Moine, B., Loris, H.N.B.T., 2005. Geochemical characterisation, provenance, source and depositional environment of 'Roches ArgiloTalqueuses' (RAT) and Mines Subgroups sedimentary rocks in the Neoproterozoic Katangan Belt (Congo): lithostratigraphic implications. J. Afr. Earth Sci. 42, 119-133.

Kampunzu, A.B., Cailteux, J.L.H., Kamona, A.F., Intiomale, M.M., Melcher, F., 2009. Sediment-hosted $\mathrm{Zn}-\mathrm{Pb}-\mathrm{Cu}$ deposits in the Central African Copperbelt. Ore Geol. Rev. 35, 263-297.

Karaca, A., 2004. Effect of organic wastes on the extractability of cadmium, copper, nickel, and zinc in soil. Geoderma 122, 297-303.

Katemo Manda, B., Colinet, G., André, L., Chocha Manda, A., Marquet, J.-P., Micha, J.-C., 2010. Evaluation de la contamination de la chaîne trophique par les éléments traces ( $\mathrm{Cu}, \mathrm{Co}, \mathrm{Zn}, \mathrm{Pb}, \mathrm{Cd}, \mathrm{U}, \mathrm{V}$ et $\mathrm{As}$ ) dans le bassin de la Lufira supérieure (Katanga, RD Congo). Tropicultura 28, 246-252.

Lange, B., Faucon, M.P., Meerts, P., Shutcha, M., Mahy, G., Pourret, O., 2014. Prediction of the edaphic factors influence upon the copper and cobalt accumulation in two metallophytes using copper and cobalt speciation in soils. Plant Soil 379, 275-287.

Lange, B., Pourret, O., Meerts, P., Jitaru, P., Cancès, B., Grison, C., Faucon, M.-P., 2016. Copper and cobalt mobility in soil and accumulation in a metallophyte as influenced by experimental manipulation of soil chemical factors. Chemosphere 146, 75-84.

Lange, B., van der Ent, A., Baker, A.J.M., Echevarria, G., Mahy, G., Malaisse, F., Meerts, P., Pourret, O., Verbruggen, N., Faucon, M.-P., 2017. Copper and cobalt accumulation in plants: a critical assessment of the current state of knowledge. New Phytol. 213, 537-551.

Liénard, A., Colinet, G., 2016. Assessment of vertical contamination of Cd, Pb and $\mathrm{Zn}$ in soils around a former ore smelter in Wallonia, Belgium. Environ. Earth Sci. 75.

Liénard, A., Brostaux, Y., Colinet, G., 2014. Soil contamination near a former Zn-Pb oretreatment plant: evaluation of deterministic factors and spatial structures at the landscape scale. J. Geochem. Explor. 147, 107-116.

Limousin, G., Gaudet, J.P., Charlet, L., Szenknect, S., Barthès, V., Krimissa, M., 2007. Sorption isotherms: a review on physical bases, modeling and measurement. Appl. Geochem. 22, 249-275.

Lottermoser, B., 2010. Mine Wastes, 2nd Edition. Characterization, Treatment and Environmental Impacts. Springer, Berlin Heidelberg.

Mambwe, P., Milan, L., Batumike, J., Lavoie, S., Jébrak, M., Kipata, L., Chabu, M., Mulongo, S., Lubala, T., Delvaux, D., Muchez, P., 2017. Lithology, petrography and $\mathrm{Cu}$ occurrence of the Neoproterozoic glacial Mwale Formation at the Shanika syncline (Tenke Fungurume, Congo Copperbelt; Democratic Republic of Congo). J. Afr. Earth Sci. 129, 898-909.

Mohamed, I., Ahamadou, B., Li, M., Gong, C., Cai, P., Liang, W., Huang, Q., 2010. Fractionation of copper and cadmium and their binding with soil organic matter in a contaminated soil amended with organic materials. J. Soils Sediments 10, 973-982.

Mpundu Mubemba, M., Useni Sikuzani, Y., Nyembo Kimuni, L., Colinet, G., 2014. Effects of carbonate and organic amendments on two vegetable crops in contaminated soil in Lubumbashi (DR Congo). Biotechnol. Agron. Soc. Environ. 18, 367-375.

Mueller, K.K., Lofts, S., Fortin, C., Campbell, P.G.C., 2012. Trace metal speciation predictions in natural aquatic systems: incorporation of dissolved organic matter (DOM) spectroscopic quality. Environ. Chem. 9, 356-368.

Muyumba, D., Liénard, A., Mahy, G., Ngongo Luhembwe, M., Colinet, G., 2015. Caractérisation des systèmes sols-plantes dans les collines de l'arc cuprifère du Katanga (Synthèse bibliographique). Biotechnol. Agron. Soc. Environ. 19, 197-207.

Muyumba, D., Pourret, O., Liénard, A., Faucon, M.-P., Mahy, G., Colinet, G., 2018. Evaluation expérimentale de la phytodisponibilité du cuivre et du cobalt dans les sols des écosystèmes métallifères de l'arc cuprifère katangais. In: Bogaert, J., Colinet, G., Mahy, G. (Eds.), Anthropisation des paysages katangais. Presses Universitaires de Liège - Agronomie-Gembloux, Belgium.

Mwanamoki, P.M., Devarajan, N., Thevenon, F., Birane, N., de Alencastro, L.F., Grandjean, D., Mpiana, P.T., Prabakar, K., Mubedi, J.I., Kabele, C.G., Wildi, W., Poté, J., 2014. Trace metals and persistent organic pollutants in sediments from river-reservoir systems in Democratic Republic of Congo (DRC): spatial distribution and potential ecotoxicological effects. Chemosphere 111, 485-492.

Narendrula, R., Nkongolo, K.K., Beckett, P., 2012. Comparative soil metal analyses in Sudbury (Ontario, Canada) and Lubumbashi (Katanga, DR-Congo). Bull. Environ. Contam. Toxicol. 88, 187-192.

Ngongo Luhembwe, M., 2014. Soil resources in the Congo Basin: their properties and constraints for food production. In: Rammeloo, J., Van De Vijver, B., Goyens, P. (Eds.), Nutrition and Food Production in the Congo Basin. Académie Royale des Sciences D'Outre-Mer, pp. 35-54.

Ponthieu, M., Pourret, O., Marin, B., Schneider, A.R., Morvan, X., Conreux, A., Cancès, B., 2016. Evaluation of the impact of organic matter composition on metal speciation in calcareous soil solution: comparison of Model VI and NICA-Donnan. J. Geochem. Explor. 165, 1-7.

Pourret, O., Lange, B., Houben, D., Colinet, G., Shutcha, M., Faucon, M.P., 2015. Modeling of cobalt and copper speciation in metalliferous soils from Katanga (Democratic Republic of Congo). J. Geochem. Explor. 149, 87-96. 
Pourret, O., Lange, B., Bonhoure, J., Colinet, G., Decrée, S., Mahy, G., Séleck, M., Shutcha, M., Faucon, M.-P., 2016. Assessment of soil metal distribution and environmental impact of mining in Katanga (Democratic Republic of Congo). Appl. Geochem. 64, 43-55.

Saad, L., Parmentier, I., Colinet, G., Malaisse, F., Faucon, M.P., Meerts, P., Mahy, G. 2012. Investigating the vegetation-soil relationships on the copper-cobalt rock outcrops of Katanga (D. R. Congo), an essential step in a biodiversity conservation plan. Restor. Ecol. 20, 405-415.

Schuh, W., Leveille, R., Fay, I., North, R., 2012. Geology of the Tenke-Fungurume sediment-hosted strata-bound copper-cobalt district, Katanga, Democratic Republic of Congo. In: Geology and Genesis of Major Copper Deposits and Districts of the World. A Tribute to Richard H. Sillitoe, vol. 16. pp. 269-301 (Vol. Special Publication).

Séleck, M., Bizoux, J.P., Colinet, G., Faucon, M.P., Guillaume, A., Meerts, P., Piqueray, J.,
Mahy, G., 2013. Chemical soil factors influencing plant assemblages along coppercobalt gradients: implications for conservation and restoration. Plant Soil 373, 455-469.

Shutcha, M.N., Mubemba, M.M., Faucon, M.P., Luhembwe, M.N., Visser, M., Colinet, G., Meerts, P., 2010. Phytostabilisation of copper-contaminated soil in Katanga: an experiment with three native grasses and two amendments. Int. J. Phytorem. 12, 616-632.

Sparks, D.L., 2013. Environmental Soil Chemistry, third edition. Academic Press.

Sverdrup, H.U., 1990. The Kinetics of Base Cation Release Due to Chemical Weathering. Krieger Publishing Company.

USGS, 2017. Mineral Commodity Summaries 2016. U.S. Geological Surveyhttps://doi. org/10.3133/7018019. (202 pp.). 